\title{
Meliola vatsavayai, a new species from Wayanad, Kerala, India
}

V. B. Hosagoudar and M.C. Riju

\begin{abstract}
A new species of the genus Meliola, namely, $M$. vatsavayai, infected the leaves of Zanthoxylum rhetsa (Rutaceae), collected from Wayanad, has been described and illustrated in detail.

Keywords: Fungus, Meliola vatsavayai, new species Introduction

Zanthoxylum rhetsa (Roxb.) DC. (Rutaceae), a large deciduous tree with conical spines, having a great timber value for furniture and construction, found infected with a black mildew fungus. Microscopic examination of the fungus revealed that it is hitherto undescribed species of the genus Meliola. Hence, the note. Part of the collection has been deposited in $\mathrm{HClO}$, New Delhi.
\end{abstract}

\section{Meliola vatsavayaisp. nov. (Fig.1)}

Coloniae amphigenae, densae, velutinae, dispersae vel confluentes, ad $4 \mathrm{~mm}$ diam. Hyphae rectae, opposite acuteque vel laxe ramosae, arte reticulatae, cellulae 1318 x 6-11 $\mu \mathrm{m}$. Appressoria alternata, raro unilateralis, saepe dense posita, antrorsa, recta, $24-40 \mu \mathrm{m}$ longa; cellulae basilares cylindraceae vel cuneatae, 8-13 $\mu \mathrm{m}$ longae; cellulae apicales ovatae, angularis, sinuatim vel fortiter lobatae, $15-27 \times$ 9-18 $\mu \mathrm{m}$. Phialides appressoriis intermixtae, plerumque oppositae, raro alternatae vel unilateralis, ampulliformes, 22-31 x 4-9 $\mu \mathrm{m}$. Setae myceliales rectae vel leniter curvulae, dispersae vel juxta perithecia aggregatae, ad apicem obtusae, ad $270 \mu \mathrm{m}$ longae. Perithecia dispersa, ad $110 \mu \mathrm{m}$ diam.; ascosporae cylindraceae vel leniter ellipsoideae, 4-septatae, constrictae ad septatae, 37-44 x 15-20 $\mu \mathrm{m}$.

Colonies amphigenous, dense, velvety, scattered to confluent, up to $4 \mathrm{~mm}$ in diameter. Hyphae straight, branching opposite at acute to wide angles, closely reticulate, cells 13-18 x 6-11 $\mu \mathrm{m}$. Appressoria alternate, rarely unilateral, often crowded, antrorse, straight, 24-40 $\mu \mathrm{m}$ long; stalk cells cylindrical to cuneate, 8-13 $\mu \mathrm{m}$ long; head

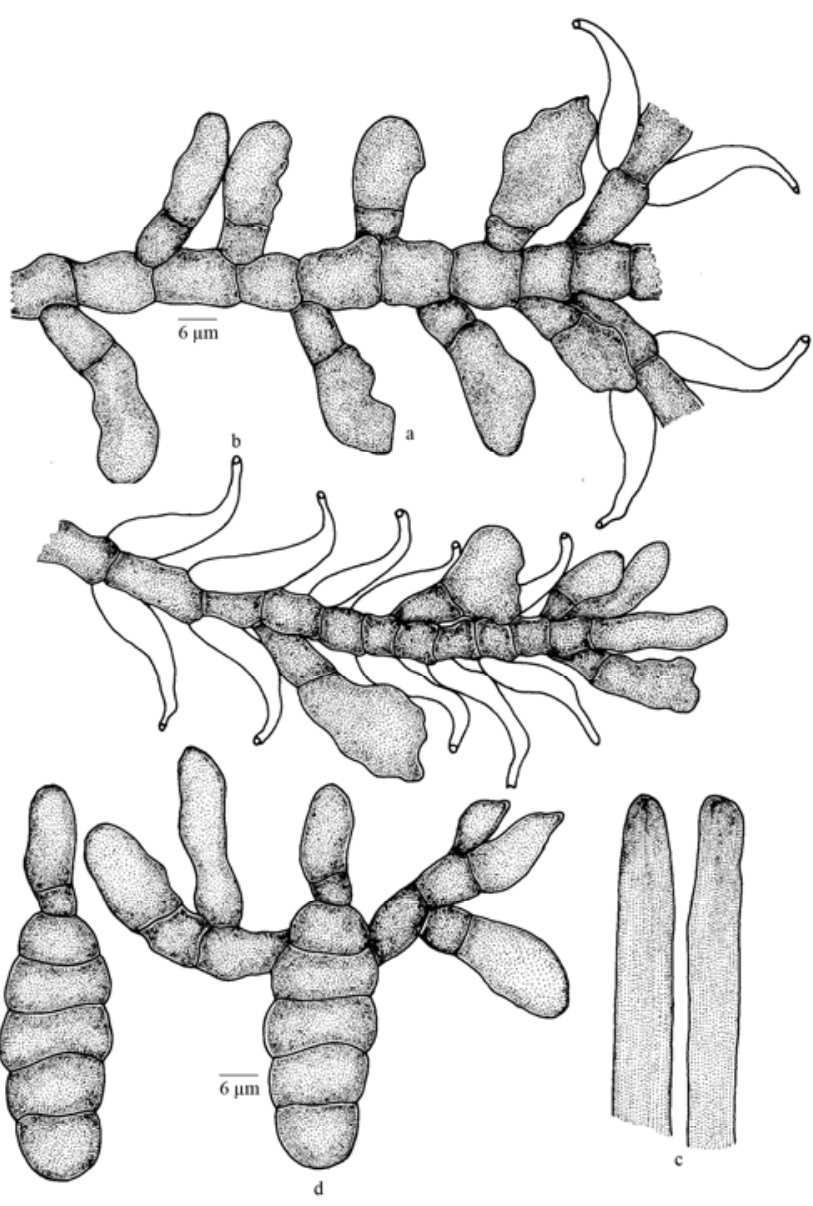

Fig. 1. Meliola vatsavayai sp nov.

a. Appressorium, b. Phialide, c. Apical portion of the mycelial setae, d. Ascospores cells ovate, angular, sinuately lobate to deeply lobate, $15-$ $27 \times 9-18 \mu \mathrm{m}$. Phialides mixed with appressoria, mostly opposite, rarely alternate to unilateral, ampulliform, 22-31 $x$ 4-9 $\mu \mathrm{m}$. Mycelial setae straight to slightly curved, scattered to grouped around perithecia, obtuse at the tip, up to $270 \mu \mathrm{m}$ long. Perithecia scattered, up to $110 \mu \mathrm{m}$ in diam.; ascospores cylindrical to slightly ellipsoidal, 4septate, constricted at the septa, 37-44 x 15-20 $\mu \mathrm{m}$.

Materials examined: On leaves of Zanthoxylum rhetsa (Roxb) DC. (Rutaceae), $16^{\text {th }}$ mile, Padinharathara, Wayanad, Kerala, India, March, 22, 2008, M.C. Riju HClO 48299 (type), TBGT 3018 (type).

Based on the digital formula 3113.4221 , this species can be compared with $M$. toddaliicola Hansf. and $M$. toddaliicola Hanf. indica Hansf. \& Thirum. known on the host genus Toddalia from Uganda and India, respectively. However, the present new species differs from both in having angular, sinuately to deeply lobate head cells of the appressoria (Hansford., 1961; Hosagoudar, 1996, 2008; Hosagoudar et al., 1997).

This species is named in honour of Prof. Vatsavaya S. Raju, Professor in Kakatiya University, Warangal, Andhra Pradesh, whose association and friendship triggered interest of the senior author $(\mathrm{VBH})$ in this group around three decades ago.

\section{References}

1. Hansford CG (1961) The Meliolaceae. Monograph. Sydowia. Beih. 2, 1-806.

2. Hosagoudar VB (1996) Meliolales of India. Botanical Survey of India, Calcutta. pp: 363.

3. Hosagoudar VB (2008) Meliolales of India, vol. II. Botanical Survey of India, Calcutta. pp: 380.

4. Hosagoudar VB, Abraham TK and Pushpangadan $P$ (1997) The Meliolineae - $A$ Supplement. Tropical Botanic Garden and Research Institute, Palode, Thiruvananthapuram, Kerala, India. pp: 201.
"Foliicolous fungi" http://www.indjst.org
Hosagoudar \& Riju Indian J.Sci.Technol. 